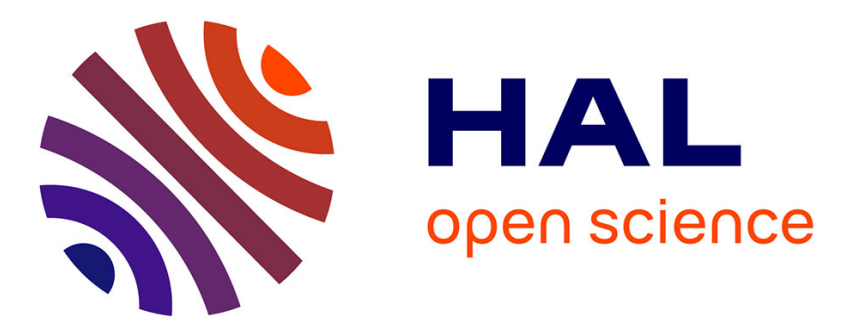

\title{
Alternative weed control using the allelopathic effect of natural benzoxazinoids from rye mulch
}

Vincenzo Tabaglio, Carolina Gavazzi, Margot Schulz, Adriano Marocco

\section{To cite this version:}

Vincenzo Tabaglio, Carolina Gavazzi, Margot Schulz, Adriano Marocco. Alternative weed control using the allelopathic effect of natural benzoxazinoids from rye mulch. Agronomy for Sustainable Development, 2008, 28 (3), pp.397-401. hal-00886420

\section{HAL Id: hal-00886420 https://hal.science/hal-00886420}

Submitted on 1 Jan 2008

HAL is a multi-disciplinary open access archive for the deposit and dissemination of scientific research documents, whether they are published or not. The documents may come from teaching and research institutions in France or abroad, or from public or private research centers.
L'archive ouverte pluridisciplinaire HAL, est destinée au dépôt et à la diffusion de documents scientifiques de niveau recherche, publiés ou non, émanant des établissements d'enseignement et de recherche français ou étrangers, des laboratoires publics ou privés. 


\title{
Alternative weed control using the allelopathic effect of natural benzoxazinoids from rye mulch
}

\author{
Vincenzo TABaglio $^{1 *}$, Carolina Gavazzi ${ }^{1}$, Margot Schulz $^{2}$, Adriano Marocco $^{1}$ \\ ${ }^{1}$ Istituto di Agronomia Generale e Coltivazioni Erbacee, Facoltà di Agraria, Università Cattolica del Sacro Cuore, Via Emilia Parmense 84, \\ 29100 Piacenza, Italy \\ ${ }^{2}$ IMBIO, University of Bonn, Karlrobert Kreiten Str. 13, 53115 Bonn, Germany
}

(Accepted 4 January 2008)

\begin{abstract}
In conventional agriculture, weed control by herbicides is an expensive practice and can also have a negative effect on the environment. Allelopathy permits sustainable weed management while reducing the impact of agriculture on the environment. We studied the content of 2,4-dihydroxy-1,4 (2H)-benzoxazin-3-one (DIBOA) and benzoxazolin-2(3H)-one (BOA), indicated as benzoxazinoids and considered effective for weed control, in 8 cultivars of rye and 1 of triticale grown in a greenhouse. We also tested the ability of mulches to inhibit the germination of four warm-season weeds. Our results show that all rye cultivars produced DIBOA, while BOA was found only in four of them. Benzoxazinoids were absent in triticale. Total benzoxazinoid content ranged from 177 to $545 \mu \mathrm{g} \mathrm{g}^{-1}$ and was statistically different among cultivars. Rye mulches were not able to suppress velvetleaf and common lambsquarters seedlings, while redroot pigweed and common purslane were significantly affected. Weed suppression ranged from $40 \%$ to $52 \%$ for redroot pigweed and from $40 \%$ to $74 \%$ for common purslane. The inhibitory activity of triticale mulch was observed only for common purslane, with a suppression percentage of $33 \%$. No correlation was found between total benzoxazinoid content and the number of weed seedlings suppressed, with $\mathrm{R}^{2}$ of 0.076 for redroot pigweed and $\mathrm{R}^{2}$ of 0.003 for common purslane, indicating that benzoxazinoids are not the only source of phytotoxicity.
\end{abstract}

allelopathy / BOA / DIBOA / integrated weed control / mulch / rye / triticale

\section{INTRODUCTION}

Modern conventional agriculture requires a high degree of inputs and technology. The herbicidal control of weeds is a costly affair and also deteriorates the quality of soil, water, animal and human health, and food (Cihacek et al., 1996; Doran and Safley, 1997; Narwal, 2006). The excessive use of herbicides can also, in some circumstances, lead to the development of resistance to synthetic chemicals and an increase in the number of herbicide-resistant weeds (Duke et al., 2002; Bhowmik and Inderjit, 2003; Batish et al., 2007). Therefore, economic and environmental constraints of crop production systems have stimulated interest in alternative weed management strategies (Anaya, 1999; Mortensen et al., 2000; Singh et al., 2001). Allelopathy refers to the inhibition of growth of a plant due to organic substances released by another organism. Allelopathy plays an important role in agroecosystems and offers the potential for selective biological weed management by the production and release of allelochemicals from leaves, flowers, seeds and roots of living or decomposing plant materials (Weston, 1996).

*Corresponding author: vincenzo.tabaglio@unicatt.it
Rye is a plant which provides excellent weed suppression through both allelopathic and competitive mechanisms. Rye residues maintained on the soil surface release the benzoxazinoids 2,4-dihydroxy-1,4 (2H)-benzoxazin-3-one (DIBOA) and benzoxazolin-2(3H)-one (BOA) (Barnes and Putnam, 1987; Friebe, 2001); both of which strongly inhibit the germination and seedling growth of several dicot- and monocotyledonous plant species. The chemical structures of DIBOA and BOA are shown in Figure 1.

Several studies have demonstrated the allelopathic characteristics of rye residues; some experiments have shown marked reductions in the germination and growth of several problematic agronomic weeds, including barnyardgrass (Echinochloa crus-galli L.), common lambsquarters (Chenopodium album L.), common ragweed (Ambrosia artemisiifolia L.), green foxtail [(Setaria viridis L.), Beauv.] and redroot pigweed (Amaranthus retroflexus L.) (Putnam and DeFrank, 1983; Shilling et al., 1985; Tabaglio and Gavazzi, 2006). Moreover, soil nutrients influence allelopathic activities significantly (Rice, 1984); Mwaja et al. (1995) found that DIBOA and $\mathrm{BOA}$ levels in greenhouse-grown rye shoots were lower under high-fertility regimes when compared with those grown 
<smiles>O=C1C(O)Oc2ccccc2N1O</smiles>

DIBOA<smiles>O=c1[nH]c2ccccc2o1</smiles>

BOA
Figure 1.

under low- and medium-fertility regimes. The production of allelopathic compounds varies within the same species and with plant age (Argandona et al., 1981). To improve management strategies for the use of allelopathic cover crops in the field, it is important to investigate if there are significant differences in total benzoxazinoid content among Secale cereale cultivars.

The present study, conducted in a greenhouse, aimed to examine the content of DIBOA and BOA in eight of the most recent and readily-available rye cultivars on the Italian market and to study the effect of mulches on four warm-season weeds. Since Niemeyer et al. (1992) reported on the presence of DIBOA in triticale, it was decided to grow one cultivar of triticale used in the Po plain together with the eight cultivars of rye.

\section{MATERIALS AND METHODS}

\subsection{Greenhouse-grown rye and triticale and determination of DIBOA and BOA}

The study involved seven cultivars (Born, Fasto, Forestier, Matador, Nikita, Primizia and Protector) and one hybrid (Treviso) of rye (Secale cereale L.) (hereafter all indicated as cv.) and one cultivar of triticale, Trimaran (Triticum secalotriticum saratoviense Meister), chosen from those most readily available on the Italian market. The study was carried out in an unheated greenhouse. The randomized block design had 9 treatments and 6 replications. 54 plastic pots $\left(59.5 \times 18 \times 14 \mathrm{~cm}\right.$, with a surface area of $\left.0.11 \mathrm{~m}^{2}\right)$ were used, each containing $12 \mathrm{~kg}$ of dry soil. The soil was a loam, with the following properties: $\mathrm{pH} 7.51$, organic matter $1.79 \%$, available $\mathrm{P} 15.6 \mathrm{mg} \mathrm{kg}^{-1}$, exchangeable $\mathrm{K} 131 \mathrm{mg} \mathrm{kg}^{-1}$ and cation exchange capacity $16.3 \mathrm{cmol}^{+} \mathrm{kg}^{-1}$. The rye and triticale were sown on 15/12/2004. 40 germinable kernels were placed in each pot. The plants were grown under unlimited water availability and were not fertilized. Each cultivar was cut at the heading stage. Shoot tissues were cut at ground level, ovendried for 3 days at $60{ }^{\circ} \mathrm{C}$, and weighed (Burgos et al., 1999). The dry shoots were cut into 1-cm lengths; for DIBOA and BOA determination samples were ground to pass through a 40-mesh screen in a Wiley mill. Ground tissues were stored in amber-colored bottles at room temperature until the extraction of allelochemicals.

The dried plant material was thoroughly mixed to obtain a homogenous distribution of fine and coarse particles. Aliquots of $80 \mathrm{mg}$ were extracted with $50 \%$ methanol $(1: 45 \mathrm{w} / \mathrm{v})$. The mixture was mortared for further homogenization for $15 \mathrm{~min}$ and centrifuged (15 min at $10000 \mathrm{~g}$ ). The supernatant was used for HPLC (Beckman Coulter pump module 126 equipped with a diode array detector 166).

For DIBOA/DIBOA-Glc determinations the following gradient was used: $0-10 \mathrm{~min} 100 \% \mathrm{~A}\left(\mathrm{H}_{2} \mathrm{O}, 0.1 \%\right.$ TFA $)$; $10-30 \min 25 \% \mathrm{~A}$ in B (methanol); 30-35 $\min 100 \%$ B. Compounds were separated with an analytical Nucleodur 100-5 C18 column (Macherey and Nagel); the detection wavelengths were 280 and $227 \mathrm{~nm}$. DIBOA and DIBOA-glc were calculated in sum using external standard curves for quantifying.

BOA determinations were performed using the isocratic system described by Reberg-Horton et al. (2005) and with the following gradients: (gradient A): $0-1$ min $100 \% \mathrm{~A}\left(\mathrm{H}_{2} \mathrm{O}\right.$, $0.1 \%$ TFA), $1-8$ min $45 \%$ A in B (methanol), $8-16$ min $32 \%$ A in B; $16-19 \min 100 \%$ B. Gradient B: $0-1 \min 100 \%$ A, $1-8 \min 60 \% \mathrm{~A}$ in B, $8-20 \min 32 \% \mathrm{~A}$ in B, $20-22 \min 100 \%$ $\mathrm{B}$. BOA determinations were run with an analytical ultrasphere ODS RP 18 column (Beckman Coulter); the detection wavelengths were 280 and $227 \mathrm{~nm}$. Calculations of content were based on external standard curves. The data obtained were from 6 different extractions. The reference compounds DIBOA and DIBOA-glc were a gift from Prof. Sicker, University of Leipzig. The BOA was purchased from Fluka.

\subsection{Preparation of mulches and sowing of weeds}

Given the limited quantity of material for the mulch, the biomass obtained for each cultivar was first reconstituted and then redistributed over half of the pots previously used, thus using only three replications. To these pots were added three control pots without mulch. On June 13th 2005, 60 viable seeds were sown in each pot and for each weed. The velvetleaf seeds (Abutilon theophrasti Medicus), redroot pigweed (Amaranthus retroflexus L.) and common lambsquarters (Chenopodium album L.) came from Herbiseed (Twyford, UK), while those of common purslane (Portulaca oleracea L.) were collected in our own fields. Immediately after sowing $10 \mathrm{~mm}$ of water was applied to each pot; the soil was then kept in conditions similar to field capacity using pot saucers. The study ended on July 15 2005; throughout the greenhouse period five counts of emerged seedlings were carried out 8,11 , 18,25 and 32 days after sowing. Seedlings which had emerged were counted at cotyledon appearance and removed.

\section{RESULTS AND DISCUSSION}

The above-ground biomass of eight $\mathrm{cv}$. of rye and triticale and the percentages of dry matter are presented in Table I. The Treviso hybrid was the least productive $(8.4 \mathrm{~g} / \mathrm{pot})$, while Primizia was the most productive $(16.9 \mathrm{~g} / \mathrm{pot})$; all the others ranged between these two, from 10.9 to $13 \mathrm{~g} /$ pot. The classification of the cultivars mostly reflects their level of earliness, as was further confirmed by the percentages of dry matter; Primizia has a higher value, of about 6 percentage points above Treviso. The earliness range was of only 10 days, much 
Table I. Dry matter yield and percentage of the eight rye cultivars and the triticale cultivar (Trimaran) grown in a greenhouse. Each mean is derived from six replications.

\begin{tabular}{lcc}
\hline Cultivars & $\begin{array}{c}\text { Dry matter } \\
(\mathrm{g} / \mathrm{pot})\end{array}$ & $\begin{array}{c}\text { Dry matter } \\
\%\end{array}$ \\
\hline Born & $11.4 \mathrm{~b}$ & $17.1 \mathrm{bc}$ \\
Fasto & $13.0 \mathrm{c}$ & $19.6 \mathrm{e}$ \\
Forestier & $10.9 \mathrm{~b}$ & $17.9 \mathrm{~d}$ \\
Matador & $11.2 \mathrm{~b}$ & $16.9 \mathrm{ab}$ \\
Nikita & $11.9 \mathrm{~b}$ & $17.7 \mathrm{~cd}$ \\
Primizia & $16.9 \mathrm{~d}$ & $22.6 \mathrm{f}$ \\
Protector & $11.7 \mathrm{~b}$ & $17.6 \mathrm{~cd}$ \\
Treviso & $8.4 \mathrm{a}$ & $16.5 \mathrm{a}$ \\
Trimaran & $11.6 \mathrm{~b}$ & $19.2 \mathrm{e}$ \\
Significance $(P)$ & 0.001 & 0.001 \\
\hline
\end{tabular}

Within the same column, means followed by the same letter are not significantly different at $P \leqslant 0.05$ according to Duncan's test.

Table II. Content of benzoxazinoids 2,4-dihydroxy-1,4 (2H)benzoxazin-3-one (DIBOA) and benzoxazolin-2(3H)-one (BOA) in the eight rye cultivars and the triticale cultivar (Trimaran) grown in a greenhouse. Each mean is derived from six replications.

\begin{tabular}{llcc}
\hline Cultivars & $\begin{array}{c}\text { DIBOA } \\
\mu \mathrm{g} \mathrm{g}^{-1} \mathrm{~d} . \mathrm{m} .\end{array}$ & $\begin{array}{c}\text { BOA } \\
\mu \mathrm{g} \mathrm{g}^{-1} \mathrm{~d} . \mathrm{m} .\end{array}$ & $\begin{array}{c}\text { DIBOA + BOA } \\
\mu \mathrm{g} \mathrm{g}^{-1} \mathrm{~d} . \mathrm{m} .\end{array}$ \\
\hline Born & $177 \mathrm{a}$ & $\mathrm{n} . \mathrm{d}$. & $177 \mathrm{a}$ \\
Fasto & $534 \mathrm{c}$ & 11 & $545 \mathrm{c}$ \\
Forestier & $338 \mathrm{~b}$ & 62 & $400 \mathrm{~b}$ \\
Matador & $329 \mathrm{~b}$ & n.d. & $329 \mathrm{ab}$ \\
Nikita & $286 \mathrm{ab}$ & 1 & $287 \mathrm{ab}$ \\
Primizia & $283 \mathrm{ab}$ & 114 & $397 \mathrm{~b}$ \\
Protector & $225 \mathrm{ab}$ & n.d. & $225 \mathrm{a}$ \\
Treviso & $266 \mathrm{ab}$ & n.d. & $266 \mathrm{ab}$ \\
Trimaran & n.d. & n.d. & n.d. \\
Significance $(P)$ & 0.001 & & 0.01 \\
\hline
\end{tabular}

n.d.: not detectable. Within the same column, means followed by the same letter are not significantly different at $P \leqslant 0.05$ according to Duncan's test.

lower than is typical for the same materials in the field, probably due to the environmental conditions in the greenhouse, which led to accelerated growth. The production of biomass was rather low, due to the conditions in the pots and in the greenhouse, which reduced the length of the growing cycle to about four months. In any case, it is known that as regards quantity and quality, production in the field is not comparable with that in the greenhouse. For example, production of the hybrid Treviso per hectare would be $764 \mathrm{~kg}$ dry matter and that of Primizia $1536 \mathrm{~kg}$, which correspond to around 30\% and $60 \%$, respectively, of the average yield of a rye cover crop under field conditions. The different productivity of the cultivars influenced the quantity of mulch used for the study of the weeds, and therefore also the quantity of allelochemicals applied in the treatments.

The average content of the benzoxazinoids 2,4-dihydroxy1,4 (2H)-benzoxazin-3-one (DIBOA) and benzoxazolin$2(3 \mathrm{H})$-one $(\mathrm{BOA})$ are presented in Table II. In contrast with
Table III. Mulch quantities obtained from the eight rye cultivars and the triticale cultivar (Trimaran) applied per pot before the sowing of the four warm-season weeds, and relative total quantities of benzoxazinoids 2,4-dihydroxy-1,4 (2H)-benzoxazin-3-one (DIBOA) and benzoxazolin-2(3H)-one (BOA).

\begin{tabular}{lcr}
\hline Cultivars & $\begin{array}{c}\text { Mulch } \\
\left(\mathrm{g} \mathrm{d} . \mathrm{m} . \mathrm{pot}^{-1}\right)\end{array}$ & $\begin{array}{c}\text { DIBOA + BOA } \\
\left(\mathrm{mg} \mathrm{pot}^{-1}\right)\end{array}$ \\
\hline Born & 21.5 & 3.807 \\
Fasto & 24.5 & 13.344 \\
Forestier & 20.5 & 8.210 \\
Matador & 21.5 & 7.058 \\
Nikita & 22.3 & 6.404 \\
Primizia & 32.5 & 12.910 \\
Protector & 21.8 & 4.906 \\
Treviso & 15.2 & 4.043 \\
Trimaran & 22.2 & 0 \\
\hline
\end{tabular}

the findings of Niemeyer et al. (1992), triticale does not contain benzoxazinoids, at least regarding the cv. Trimaran and in the experimental conditions described. Consequently, triticale was excluded from the statistical analysis. All 8 varieties of rye produce DIBOA, while only 4 also produce $\mathrm{BOA}$ in traceable quantities. For this reason the BOA content was not statistically analyzed, while the total benzoxazinoid content was calculated. The DIBOA content of rye mulch is statistically different among cultivars $(P<0.001)$, going from 177 (cv. Born) to $534 \mu \mathrm{g} \mathrm{g}^{-1}$ (cv. Fasto), although Duncan's test only distinguishes the cv. Fasto from all the others. Considering the $\mathrm{BOA}$ as well, the total benzoxazinoid content still differs significantly for the 8 rye cultivars $(P<0.01)$, with Fasto, Forestier and Primizia in the first three positions, while the cv. Born presents the lowest value, which is about $1 / 3$ of that of Fasto.

To check the allelopathic effect of rye residues on weeds, pots were prepared with the quantities of mulch - and consequently of benzoxazinoids - presented in Table III. Because of differences in the production of biomass and in the allelochemical content, the treatments were characterized by quite varied conditions. The amounts of mulch ranged from 15.2 (Treviso) to $32.5 \mathrm{~g} /$ pot (Primizia). As regards the total benzoxazinoid amounts applied, and excluding triticale which contained none, the lowest value was that for Born, with less than $4 \mathrm{mg}$ per pot, while Fasto and Primizia had values of around 13.

The number of weed seedlings at 32 days after planting is presented in Table IV. The analysis of variance indicates the absence of significant effects for velvetleaf and common lambsquarters, while for redroot pigweed and common purslane significance goes from $1 \%$ to $1 \%$. As regards velvetleaf, as found in a previous study (Tabaglio and Gavazzi, 2006), rye mulch does not manifest any control and tends rather to encourage germination, probably due to the higher humidity of the mulched soil. The eight mulches of rye are statistically different compared with the control for redroot pigweed and common purslane, while triticale mulch is effective only for common purslane. The rye mulches are not statistically different from each other. For redroot pigweed, at a level of probability of 5\% it is clear that only rye cultivars, with the exclusion 
Table IV. Number of weed seedlings counted up to 32 days after sowing. Figures are percentages over control. The data represent the seedlings which emerged from the mulch obtained from the eight rye cultivars and the triticale cultivar (Trimaran). For each cultivar three pots were used, to which the mulch was applied. To these pots were added three control pots without mulch. In each pot and for each weed 60 viable seeds were sown. Each mean is derived from three replications.

\begin{tabular}{lcccc}
\hline Cultivars & $\begin{array}{c}\text { Abutilon } \\
\text { theophrasti }\end{array}$ & $\begin{array}{c}\text { Amaranthus } \\
\text { retroflexus }\end{array}$ & $\begin{array}{c}\text { Chenopodium } \\
\text { album }\end{array}$ & $\begin{array}{c}\text { Portulaca } \\
\text { oleracea }\end{array}$ \\
\hline Born & 118 & $55 \mathrm{a}$ & 107 & $47 \mathrm{ac}$ \\
Fasto & 106 & $54 \mathrm{a}$ & 103 & $48 \mathrm{ac}$ \\
Forestier & 125 & $60 \mathrm{ab}$ & 104 & $60 \mathrm{bc}$ \\
Matador & 142 & $48 \mathrm{a}$ & 101 & $36 \mathrm{ab}$ \\
Nikita & 120 & $54 \mathrm{a}$ & 98 & $30 \mathrm{a}$ \\
Primizia & 123 & $52 \mathrm{a}$ & 89 & $34 \mathrm{ab}$ \\
Protector & 120 & $60 \mathrm{ab}$ & 84 & $26 \mathrm{a}$ \\
Treviso & 106 & $81 \mathrm{bc}$ & 92 & $48 \mathrm{ac}$ \\
Trimaran & 122 & $86 \mathrm{c}$ & 96 & $67 \mathrm{c}$ \\
Control & 100 & $100 \mathrm{c}$ & 100 & $100 \mathrm{~d}$ \\
Significance $(P)$ & $n . s$. & 0.01 & $n . s$. & 0.001 \\
\hline
\end{tabular}

Analysis was performed using real data. n.s. = not significant. Within the same column, means followed by the same letter are not significantly different at $P \leqslant 0.05$ according to Duncan's test.

of Treviso, differ from the control. The greatest weed suppression occurred with the mulch of the $\mathrm{cv}$. Matador $(-52 \%$ compared with the control), while at the other extreme were Treviso (-19\%) and Trimaran (-14\%). For common purslane, all the mulches were effective; the greatest weed suppression was achieved with Protector $(-74 \%)$, and good results were also obtained with Treviso $(-52 \%)$ and with triticale, which was, however, the least effective $(-33 \%)$. The results obtained confirm that larger-seeded species are less sensitive to allelochemicals (Chase et al., 1991) and that seed mass is particularly important for the selective suppression of weeds with crop residues (Mohler, 1996; Liebman and Davis, 2000). Therefore, it is difficult to explain the failure to suppress Chenopodium album, because the suppressive effect was also observed in our previous study (Tabaglio and Gavazzi, 2006).

To verify the direct effect of allelochemicals, the relationship between the efficacy in weed suppression and the quantities of benzoxazinoids from the mulches was studied by means of linear regression. The equations obtained for redroot pigweed and common purslane were $y=0.0004 x+12.167$ with $\mathrm{R}^{2}=0.076$, and $\mathrm{y}=-0.0002 \mathrm{x}+42.249$ with $\mathrm{R}^{2}=0.003$, respectively.

There is no correlation between total benzoxazinoids and the number of seedlings suppressed; in fact, the $\mathrm{R}^{2}$ calculated are completely irrelevant. With these results it cannot be affirmed that there is no allelopathic effect; it can be affirmed, however, that in our conditions the effect of mulches is not only due to their DIBOA or BOA contents. Other allelochemicals, such as the nine acids identified by Chou and Patrick (1976), or B-phenyllactic acid (ß-PLA) or ß-hydroxybutyric acid (B-HBA) found by Shilling et al. (1986a, b), which are effective on redroot pigweed and common lambsquarters, may have interacted with the competitive effect of rye residues.

\section{CONCLUSION}

The study demonstrates that there are significant differences in benzoxazinoid content between the rye cultivars grown. Rye mulches were not able to suppress velvetleaf and common lambsquarters seedlings, while redroot pigweed and common purslane were significantly affected. No correlation was found between total benzoxazinoid content (DIBOA $+\mathrm{BOA})$ and the number of weed seedlings suppressed, suggesting that benzoxazinoids are not the only source of phytotoxicity.

Our results confirm that the use of rye mulch represents a sustainable weed management practice permitting a decrease in the amount of herbicides used in agroecosystems, for instance by eliminating the need for pre-emergence applications. Allelopathy can contribute to reducing crop production costs and environmental risks caused by an excessive use of herbicides.

Acknowledgements: The authors thank Mona Knop for assistance with DIBOA and BOA determination and Prof. Sicker for the generous gift of reference compounds.

\section{REFERENCES}

Anaya A.L. (1999) Allelopathy as a tool in the management of biotic resources, Crit. Rev. Plant Sci. 18, 697-739.

Argandona V.H., Niemeyer H.M., Corcuera L.J. (1981) Effect of content and distribution of hydroxamic acids in wheat on infestation by the aphid Schizaphis graminum, Phytochemistry 20, 673-676.

Barnes J.P., Putnam A.R. (1987) Role of benzoxazinones in allelopathy by rye (Secale cereale L.), J. Chem. Ecol. 13, 889-906.

Batish D.R., Singh H.P., Setia N., Kohli R.K., Kaur S., Yadav S.S. (2007) Alternative control of littleseed canary grass using eucalypt oil, Agron. Sustain. Dev. 27, 171-177.

Bhowmik P.C., Inderjit (2003) Challenges and opportunities in implementing allelopathy for natural weed management, Crop Prot. 22, $661-671$

Burgos N.R., Talbert R.E., Mattice J.D. (1999) Cultivar and age differences in the production of allelochemicals by Secale cereale, Weed Sci. 47, 481-485.

Chase W.R., Nair M.G., Putnam A.R. (1991) 2,2'-oxo-1, 1'-azobenzene: selective toxicity of rye (Secale cereale L.) allelochemicals to weed and crop species: II, J. Chem. Ecol. 17, 9-19.

Chou C.H., Patrick Z.A. (1976) Autointoxication mechanisms of Oryza sativa $\mathrm{L}$. Phytotoxic effects of decomposing rice residues in soil, J. Chem. Ecol. 2, 353-367.

Cihacek L.J., Anderson W.L., Barak P.W. (1996) Linkages between Soil Quality and Plant, Animal, and Human Health, in: Doran J.W., Jones A.J. (Eds.), Methods for Assessing Soil Quality, SSSA Special Publication Number 49, Soil Science Society of America, Madison, WI, USA, pp. 9-23.

Doran J.W., Safley M. (1997) Defining and Assessing Soil Health and Sustainable Productivity, in: Pankhurst C.E., Doube B.M., Gupta V.V.S.R. (Eds.), Biological Indicators of Soil Health. CAB International, Oxon, UK, pp. 1-28.

Duke S.O., Dayan F.E., Rimando R.M., Schrader K.K., Aliotta G., Oliva A., Romagni J.G. (2002) Chemicals from nature for weed management, Weed Sci. 50, 138-151. 
Friebe A. (2001) Role of Benzoxazinones in Cereals, in: Kohli R.K., Singh H.P., Batish D.R. (Eds.), Allelopathy in Agroecosystems, Food Products Press, The Haworth Press, Binghamton, NY, USA, pp. 379-400.

Liebman M., Davis A.S. (2000) Integration of soil, crop and weed management in low-external-input farming systems, Weed Res. 40, $27-47$.

Mohler C.L. (1996) Ecological bases for the cultural control of weeds, J. Prod. Agr. 9, 468-474.

Mortensen D.A., Bastiaans L., Sattin M. (2000) The role of ecology in the development of weed management systems: an outlook, Weed Res. 40, 49-62.

Mwaja V.N., Masiunas J.B., Weston L.A. (1995) Effects of fertility on biomass, phytotoxicity, and allelochemical content of cereal rye, J. Chem. Ecol. 21, 81-96.

Narwal S.S. (2006) Allelopathy in ecological sustainable agriculture, in: Reigosa M.J., Pedrol N., González L. (Eds.), Allelopathy: A Physiological Processes with Ecological Implications. Springer, Dordrecht, The Netherlands, pp. 537-564.

Niemeyer H.M., Copaja S.V., Barria N.B. (1992) The Triticeae as sources of hydroxamic acids, secondary metabolites in wheat conferring resistance against aphids, Hereditas 116, 295-299.

Putnam A.R., DeFrank J. (1983) Use of phytotoxic plant residues for selective weed control, Crop Prot. 2, 173-181.

Reberg-Horton S.C., Burton J.D., Danehower D.A., Ma G., Monks D.W., Murphy J.P., Ranells N.N., Williamson J.D., Creamer N.G. (2005)
Changes over time in the allelochemical content of ten cultivars of rye (Secale cereale L.), J. Chem. Ecol. 31, 179-193.

Rice E.L. (1984) Allelopathy (2nd ed.), Academic Press, Orlando, FL, USA.

Shilling D.G., Liebl R.A., Worsham A.D. (1985) Rye and wheat mulch: The suppression of certain broad-leaved weeds and the isolation and identification of phytotoxins, in: Thompson A.C. (Ed.), The chemistry of allelopathy: Biochemical interactions among plants. American Chemical Society, Washington, DC, USA, pp. 243-271.

Shilling D.G., Jones L.A., Worsham A.D., Parker C.E., Wilson R.F (1986a) Isolation and identification of some phytotoxic compounds from aqueous extracts of rye (Secale cereale L.), J. Agr. Food Chem. 34, 633-638.

Shilling D.G., Worsham A.D., Danehower D.A. (1986b) Influence of mulch, tillage and diphenemid on weed control, yield and quality in no-till flue cured tobacco (Nicotiana tabacum), Weed Sci. 34, 738-744

Singh H.P., Batish D.R., Kohli R.K. (2001) Allelopathy in Agroecosystems: An Overview, in: Kohli R.K., Singh H.P., Batish D.R. (Eds.), Allelopathy in Agroecosystems. Food Products Press, The Haworth Press, Binghamton, NY, USA, pp. 1-41.

Tabaglio V., Gavazzi C. (2006) Effetti dei residui di segale sulle infestanti estive del mais, Inf. Agr. 62, 37-40.

Weston L.A. (1996) Utilization of allelopathy for weed management in agroecosystems, Agron. J. 88, 860-866. 